\title{
Pityriasis Rosea in Chronic Hepatitis C
}

\author{
Viroj Wiwanitkit
}

Surin Rajabhat University, Surin, Thailand

Dear Editor,

The report on "Pityriasis rosea (PR) in chronic hepatitis C" is very interesting (1). Güner et al. (1) noted that this is "the first case of PR found in a patient with chronic hepatitis $C$ while receiving Pegylated interferon (PEG-IFN) alpha $2 \mathrm{~b}$ and ribavirin." In fact, the cause of the existence of PR in hepatitis $\mathrm{C}$ is an interesting issue. Recurrence of hepatitis $\mathrm{C}$ following existence of PR is possible (2). The PR is mentioned because of its association with reactivation of human herpesvirus-6 (3) and human herpesvirus- 6 can increase the severity of clinical features of hepatitis $C$ infection (4). In the present case, whether PR previously existed or not is still inconclusive. Finally, it should be noted that there is at least one previous report on $\mathrm{PR}$ in a chronic hepatitis $\mathrm{C}$ patient receiving PEG-IFN alpha $2 \mathrm{~b}$ and ribavirin (2).

Conflict of Interest: No conflict of interest was declared by the authors.

\section{REFERENCES}

1. Güner R, Keske S, Hasanoğlu I, Taşyaran M. Pityriasis rosea associated with pegylated interferon alfa and ribavirin treatment in a patient with chronic hepatitis C. Balkan Med J 2013;30:253-4.

2. Drago F, Javor S, Parodi A. Recurrence of hepatitis C virus infection during pityriasis rosea. Acta Derm Venereol 2013;93:483.

3. Broccolo F, Drago F, Careddu AM, Foglieni C, Turbino L, Cocuzza CE, et al. Additional evidence that pityriasis rosea is associated with reactivation of human herpesvirus-6 and -7. J Invest Dermatol 2005;124:123440.

4. Singh N, Husain S, Carrigan DR, Knox KK, Weck KE, Wagener MM, et al. Impact of human herpesvirus- 6 on the frequency and severity of recurrent hepatitis $\mathrm{C}$ virus hepatitis in liver transplant recipients. Clin Transplant 2002;16:92-6.

\section{AUTHORS' REPLY}

Rahmet Güner ${ }^{1}$, Şiran Keske², İmran Hasanoğlu Mehmet A. Taşyaran ${ }^{1}$

${ }^{1}$ Department of Infectious Diseases and Clinical Microbiology, Yıldırım Beyazıt University Faculty of Medicine, Ankara, Turkey ${ }^{2}$ Department of Infectious Diseases and Clinical Microbiology,

Giresun University Faculty of Medicine, Giresun, Turkey

${ }^{3}$ Department of Infectious Diseases and Clinical Microbiology, Van State Hospital, Van, Turkey

Dear Editor, some viral agents such as human herpesvirus-6 and human herpesvirus-7 are suspected to be the aetiological pathogens of Pityriasis rosea (PR), but it is not yet clear $(1,2)$. Based on our patient's anamnesis, PR did was considered to have not previously existed in our patient, and firstly emerged while receiving Pegylated interferon (PEG-IFN) alpha $2 \mathrm{~b}$ and ribavirin (3). Finally, we took the available resources into account when our case report was in progress. Hence, we reported it as the first case.

Address for Correspondence: Şiran Keske, Department of Infectious Diseases and Clinical Microbiology, Giresun University Faculty of Medicine, Giresun, Turkey

Phone: +90 3126212500 e-mail: doktorsiran@yahoo.com.tr

\section{REFERENCES}

1. Drago F, Broccolo F, Rebora A. Pityriasis rosea: An update with a critical appraisal of its possible herpesviral etiology. J Am Acad Dermatol 2009;61:303-18.[CrossRef]

2. Canpolat KB, Adisen E, Bozdayi G, Yucel A, Fidan I, Aksakal N, et al. The role of human herpesvirus 6, human herpesvirus 7, Epstein-Barr virus and cytomegalovirus in the aetiology of pityriasis rosea. $J$ Eur Acad Dermatol Venereol 2009;23:16-21.[CrossRef]

3. Güner R, Keske S, Hasanoğlu I, Taşyaran M. Pityriasis rosea associated with pegylated interferon alfa and ribavirin treatment in a patient with chronic hepatitis C. Balkan Med J 2013;30:253-4.[CrossRef]

Address for Correspondence: Dr. Viroj Wiwanitkit, Surin Rajabhat University, Surin, Thailand

Phone: +66 892348832 e-mail: wviroj@yahoo.com

Received: 24.10.2014 Accepted: 24.09.2014 • DOI: 10.5152/balkanmedj.2014.14778 